\title{
Harmonics and THD analysis of Five phase Inverter Drive with Single Tuned Filter using Simulink/MATLAB
}

\author{
Dr.Manjesh \\ Dept. of Electronic Science \\ Bangalore University \\ Bangalore, India \\ Manjesh1972@gmail.com
}

\author{
Ananda A S \\ Dept. of Electronic Science \\ Bangalore University \\ Bangalore, India \\ a.sanand@yahoo.com
}

\begin{abstract}
This paper aims at the reduction of harmonics in Five phase inverter drive using Single tuned filter. This filter eliminates most of the harmonic content at the output AC voltage/current before connecting to any load or grid. Inverter designs performance will be improved by minimizing fewer harmonics accurately by connecting a single tuned filter. Five phase inverter drive is more useful design, gives better performance than the conventional three phase inverter. This method is verified by constructing five phase PWM Five phase inverter drive with and without single tuned filter using Simulink/MATLAB, the results obtained are compared and same is presented. The harmonic content and Total Harmonic Distortion is compared with normal Five Phase Inverter drive with Single tuned filter connected at the output of the inverter.
\end{abstract}

Keywords- five phase; harmonics; inverter drive; THD; filters; single tuned filter;

\section{INTRODUCTION}

Industries use induction motors abundantly due to its various advantages. As the technology is developing the new motor drive designs have been introduced according to the user requirements. Recent technological advancement brings the new ideas in the industries to choose the best designs for their choices. The present scenario shows that increased use of three phase induction motor in the industries all over the world. As researchers working on various drive designs in ASD (Adjustable Speed Drives) using VSI (Voltage Source Inverter) and CSI (Current Source Inverter), performance is the key role that satisfy the user, harmonics are major effects in PWM inverters, this become challenge for the researchers to eliminate or suppress the harmonics at the output of the inverter drive that cause many problems to the load as well as the inverter drive.

Advancement in the power electronics leads to the introduction of Multi/poly phase induction motors in the mechanical world. As the number of phases are increased the advantages increases gradually, three phase induction motor is the most used device but five phase induction motor is preferred over the conventional three phase induction motor due to its various advantages such as reducing the amplitude and increasing the frequency of torque pulsation, reducing the rotor harmonic current per phase without increasing the

Identify applicable sponsor/s here. If no sponsors, delete this text box (sponsors) voltage per phase, lowering the dc-link current harmonics and higher reliability, high fault tolerance [1].

The Application oriented research increased these days, the main application areas of multi/poly phase induction motor drives are ship propulsion, traction (including electric and hybrid electric vehicles) and the concept of more-electric aircraft, locomotive traction, aerospace and high power applications [2-7].

In all inverter drives the major problem occurs when the harmonic arises, Harmonic contents are both in current and voltages. Inverter consists of non-linear elements such as switches, which produces odd harmonics and it is superimposed on the fundamental harmonic frequency. The harmonics in any power systems cuase heating in the device and conductors, misfiring in adjustable speed drives, poor power factor and torque pulsations in motors. Most of the researchers worked on harmonics to eliminate or suppress the content of the harmonics also incorporated many design techniques, used many types of filters to mitigate the harmonics in the inverter. In five phase inverter drive the leading harmonic content is the $3^{\text {rd }}$ harmonic order. The $5^{\text {th }}$ and every $5^{\text {th }}$ multiples harmonic order is absent in the five phase inverter drive. The concern now is that to reduce the harmonics effectively before connecting to the load or to the grid.

To reduce the harmonics filters are efficiently used, filters changes amplitude and phase of a voltage with frequency, filters have wide applications in power electronic system to reject and allow certain range of frequencies. The passive elements give drastic reduction of harmonic content and THD. A harmonic filter is a circuit used to block the content of different harmonic orders from coupling source to the load. The harmonics will affect to the low impedance devices. Many of the harmonic filters designs are available today and it consists of parallel connected capacitor and inductor circuits to create a low impedance device. These filters will be considered as passive devices. The passive devices attract harmonic current from the sources connected to the system. Most of the designer use passive filters to mitigate the harmonics, in this paper a passive shunt filter a single tuned filter are used. Advantage of this filter is that it 
is simple to design and less expensive to implement. A single-tuned filter consists of a capacitor in series with an inductor. The capacitor and inductor values are designed such that the branch impedance becomes zero nearby harmonic order frequency, which bypasses that harmonic order. The capacitor provides reactive power compensation accordance with total power. A resistor used to adjust the tunings sharpness maintaining the bandwidth [8-12].

\section{A. Design of the single tuned filter:}

Single tuned filter can be designed by considering the quality factor $Q$. The quality factor can be calculated using the formula (1).

$$
Q=\frac{\sqrt{L / C}}{R}
$$

Where L, C and R represents inductor, capacitor and resistor respectively. While designing the single tuned filter the inductive $\mathrm{X}_{\mathrm{L}}$ and capacitive reactance $\mathrm{X}_{\mathrm{C}}$ should be equal for resonance as shown in equation (2).

$$
\mathrm{X}_{\mathrm{L}}=\mathrm{X}_{\mathrm{C}}
$$

$\mathrm{X}_{\mathrm{C}}=\frac{1}{\omega C}$ and $\mathrm{X}_{\mathrm{L}}=\omega \mathrm{L}$, where $\omega=2 \pi \mathrm{f}$. $\mathrm{f}=$ fundamental frequency.

\section{FIVE PhaE INVERTER DRIVE}

Five phase inverter drive constructed using 10 IGBT switches as shown in Fig. 1. Five Phase signals generated by pulse generator P1-P10, the switches S1-S10 are turned on for a period of $180^{\circ}$ conduction mode with $72^{\circ}$ out of phase with each phase leg. Inverter output voltage can be obtained by proper switching on and off of IGBT's.

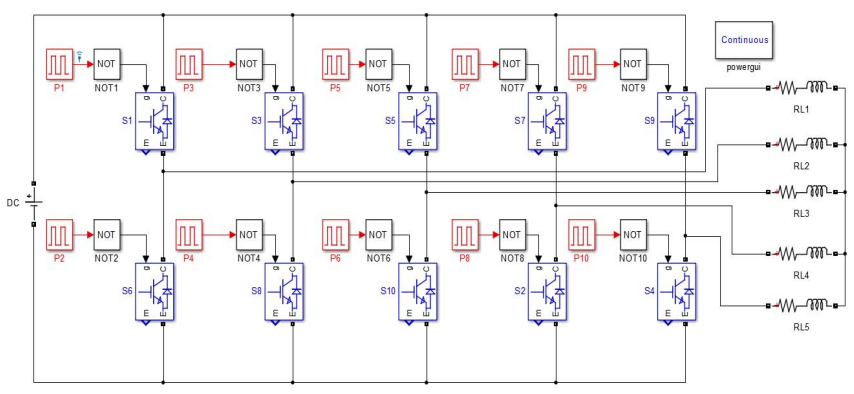

Fig.1. Circuit diagram of five phase inverter drive

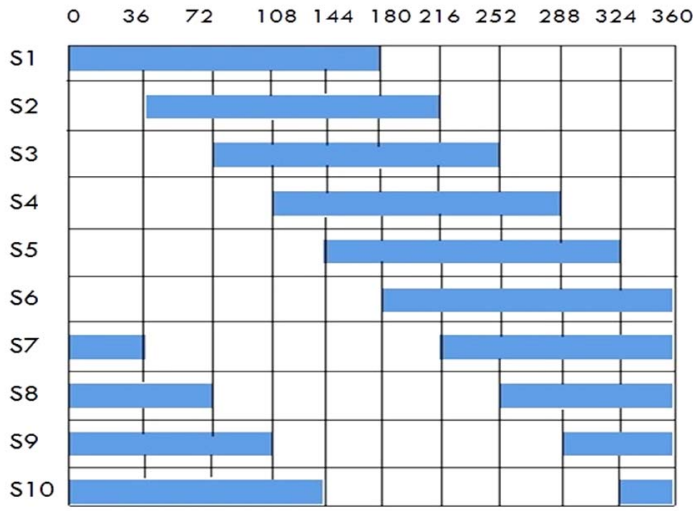

Fig. 2. Switching sequence of inverter switches
Two switch from the upper group and three switches from the lower group is on, or two from the lower group and three from the upper group is on. The switching sequence of the five phase inverter is as shown in Fig. 2.

\section{FIVE PHASE INVERTER WITH SINGLE TUNED FILTER}

Five phase inverter drive is connected with single tuned filter as shown in Fig 3. The single tuned filter designed values are $C=22 \mu F, L=0.86$ and $R=87 \Omega$. Table I shows the $\mathrm{RLC}$ values are used in the experiment.

TABLE I. R, L AND C DESIGNED VALUES FOR SINGLE TUNE FREQUENCY OF $50 \mathrm{~Hz}$

\begin{tabular}{|c|c|}
\hline Components & Values \\
\hline Resistor $\mathrm{R}_{1}-\mathrm{R}_{5}$ & $87 \Omega$ \\
\hline Capacitor $\mathrm{C}_{1} \mathrm{C}_{5}$ & $22 \mu \mathrm{F}$ \\
\hline Inductor $\mathrm{L}_{1}-\mathrm{L}_{5}$ & 0.86 \\
\hline
\end{tabular}

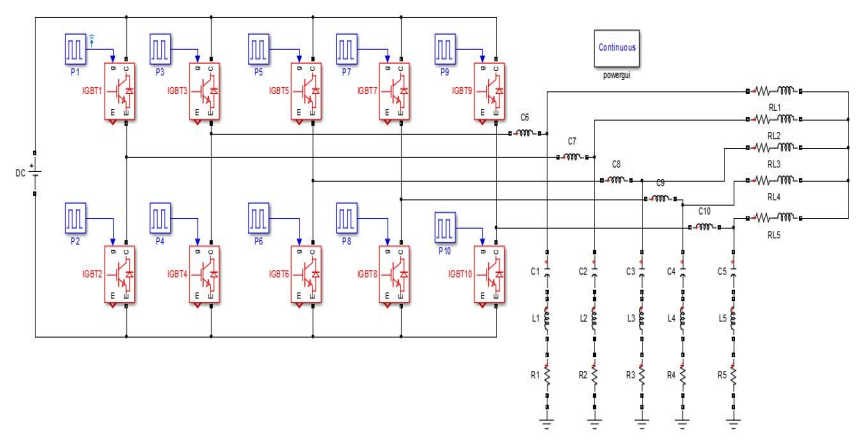

Fig. 3. Circuit Diagram of five phase inverter with single tuned filter

\section{Simulation RESUlts}

Simulation has been done for the two input frequency of $50 \mathrm{~Hz}$ for rated speed applications and $7 \mathrm{~Hz}$ for lower speed applications, with $\mathrm{RL}$ load with $\mathrm{R}=1.7 \Omega$ and $\mathrm{L}=1.3 \mathrm{mH}$. The line output voltage is measured and plotted for five phase PWM inverter without filter and with single tuned filter. THD is measured for both normal inverters without filter and with single tuned filter.

\section{A. For Input frequency $50 \mathrm{~Hz}$ :}

The line voltage waveforms of five phase PWM inverter for $50 \mathrm{~Hz}$ are as shown in Fig. 4. The line voltage waveforms five phase inverter with single tuned filter for $5 \mathrm{~Hz}$ is as shown in Fig. 5.

The THD (Total Harmonic Distortion) in Five phase inverter drive without and with filter is as shown in table II. The FFT analysis has been done for the inverter output voltage with and without filter modes and these are presented in Fig. 6 and Fig. 7 respectively. 


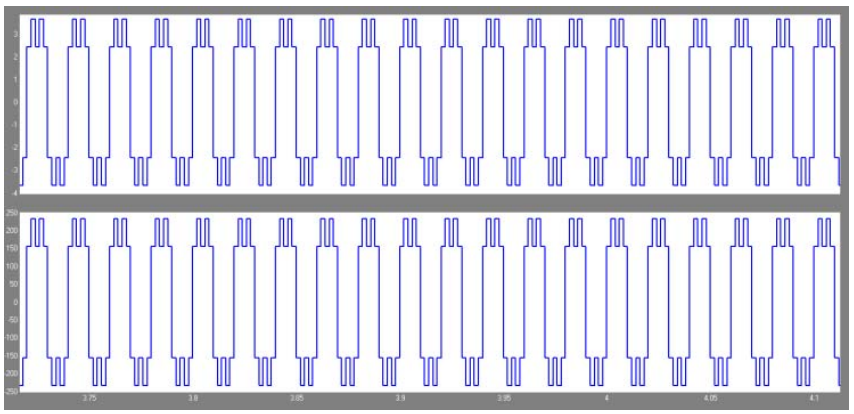

Fig. 4. Line voltage and line current waveforms of a phase in normal Five phase PWM inverter for $50 \mathrm{~Hz}$
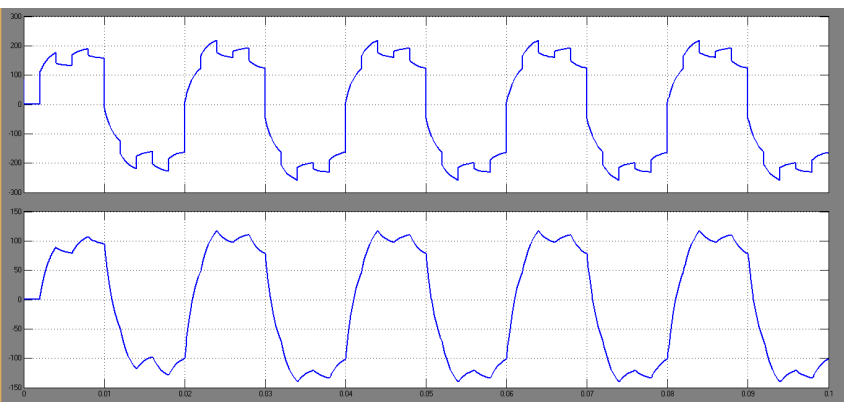

Fig. 5. Line voltage and line current waveforms of an individual phase in Five phase PWM inverter with single tuned filter for $50 \mathrm{~Hz}$.

TABLE II. THD COMPARISON OF FIVE PHASE INVERTER DRIVE WITH AND WITHOUT FILTER FOR F=50 Hz

\begin{tabular}{|c|c|}
\hline Modes & THD in $\%$ \\
\hline $\begin{array}{c}\text { Five phase inverter } \\
\text { Drive (Without Filter) }\end{array}$ & 42.7 \\
\hline $\begin{array}{c}\text { Five Phase Inverter } \\
\text { Drive With Single } \\
\text { Tuned filter }\end{array}$ & 26.19 \\
\hline
\end{tabular}

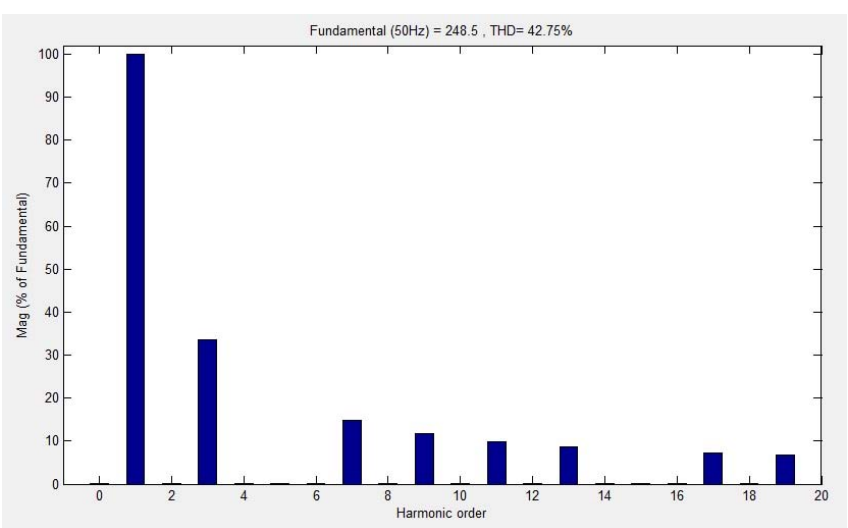

Fig. 6. FFT sequence of normal five phase inverter drive for $f_{\text {in }}=50 \mathrm{~Hz}$

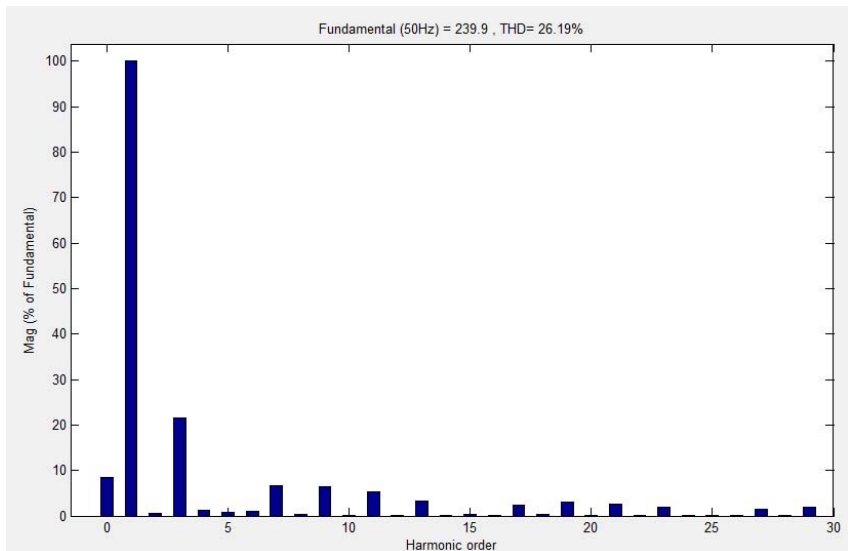

Fig. 7. FFT sequence of Five phase inverter drive with single tuned filter for $f_{\text {in }}=50 \mathrm{~Hz}$

Using Simulink/MATLAB the individual harmonic order voltage can be calculated for the inverter with and without filter, the same are presented in Table III.

TABLE III. INDIVIDUAL VOLTAGE HARMONIC ORDER AT THE OUTPUT OF AN INVERTER WITH AND WITHOUT FILTER FOR F $=50 \mathrm{HZ}$

\begin{tabular}{|c|c|c|}
\hline Harmonic Order & $\begin{array}{c}\text { Five Phase } \\
\text { Inverter Drive (V) }\end{array}$ & $\begin{array}{c}\text { Five Phase } \\
\text { inverter Drive } \\
\text { with filter (V) }\end{array}$ \\
\hline 1 & 248.28 & 243.37 \\
\hline 2 & 0 & 0 \\
\hline 3 & 82.76 & 58.13 \\
\hline 4 & 0 & 0 \\
\hline 5 & 0 & 3.13 \\
\hline 6 & 0 & 0 \\
\hline 7 & 35.47 & 20.31 \\
\hline 8 & 0 & 0 \\
\hline 9 & 27.59 & 17.09 \\
\hline 10 & 0 & 0 \\
\hline 11 & 22.57 & 13.66 \\
\hline 12 & 0 & 0 \\
\hline 13 & 19.1 & 10.13 \\
\hline 14 & 0 & 0 \\
\hline 15 & 0 & 0.94 \\
\hline 16 & 0 & 0 \\
\hline 17 & 14.6 & 7.61 \\
\hline 18 & 0 & 0 \\
\hline 19 & 13.06 & 7.60 \\
\hline
\end{tabular}

\section{B. For Input Frequency $7 \mathrm{~Hz}$ :}

The FFT analysis of Five phase inverter drive without and with filter for an input frequency of $f_{i n}=7 \mathrm{~Hz}$ and Vin $=28 \mathrm{~V}$ are used to study the Individual harmonics and THD as shown in Fig. 8 and Fig 9 respectively, the results have been presented shown in table IV. 
2016 International Conference on Emerging Technological Trends [ICETT]

TABLE IV. THD COMPARISON OF FIVE PHASE INVERTER DRIVE WITH AND WITHOUT FILTER FOR $\mathrm{F}=7 \mathrm{~Hz}$

\begin{tabular}{|c|c|}
\hline Modes & THD in \% \\
\hline $\begin{array}{c}\text { Five phase inverter } \\
\text { Drive (Without Filter) }\end{array}$ & 43.29 \\
\hline $\begin{array}{c}\text { Five Phase Inverter } \\
\text { Drive With Single } \\
\text { Tuned filter }\end{array}$ & 23.73 \\
\hline
\end{tabular}

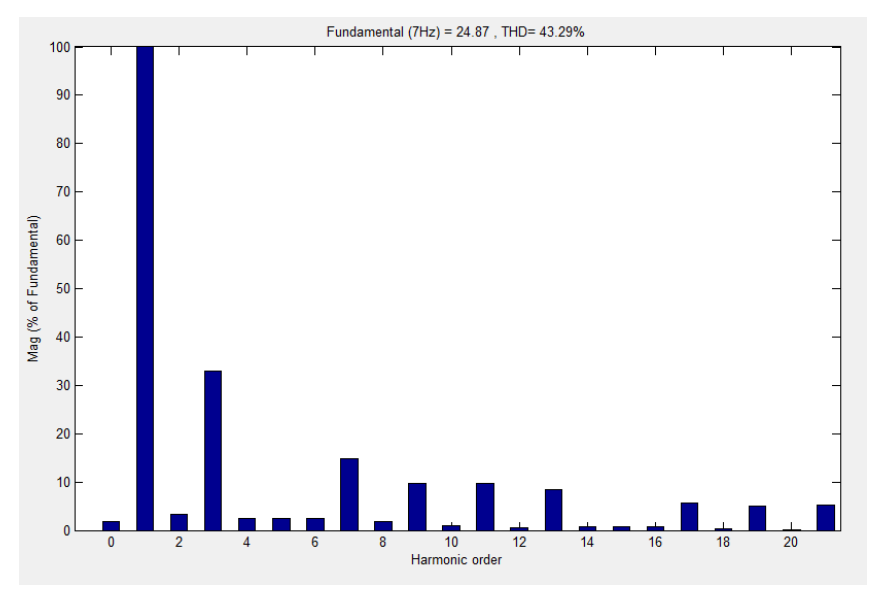

Fig. 8. FFT sequence of normal five phase inverter drive for $f_{i n}=7 \mathrm{~Hz}$

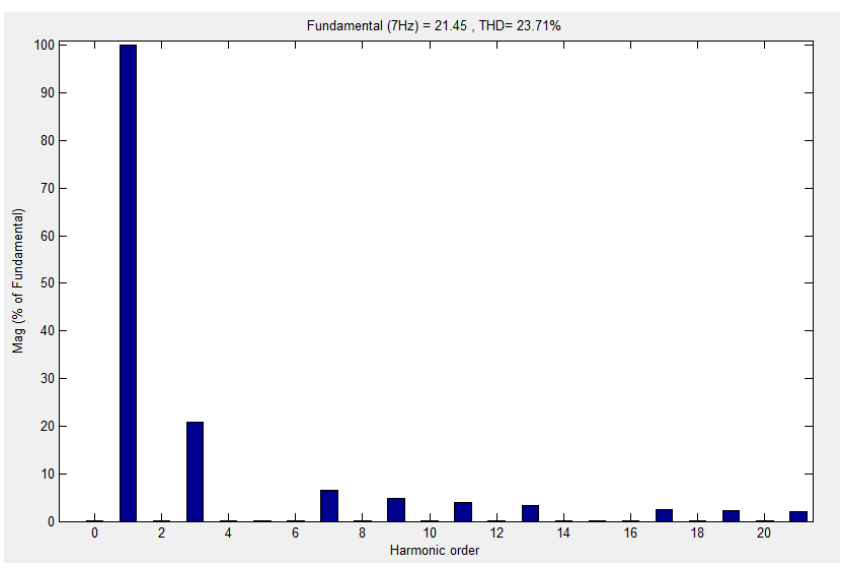

Fig. 9. FFT sequence of Five phase inverter drive with single tuned filter for $f_{i n}=7 \mathrm{~Hz}$

Percentage of Individual harmonic order is obtained for the inverter with and without filter the same are presented in Table V.

TABLE V. INDIVIDUAL HARMONIC ORDER PERCENTAGE IN THE OUTPUT VOLTAGE WITH AND WITHOUT FILTER FOR FIN $=7 \mathrm{~Hz}$

\begin{tabular}{|c|c|c|}
\hline Harmonic Order & $\begin{array}{c}\text { Five Phase } \\
\text { Inverter Drive } \\
(\%)\end{array}$ & $\begin{array}{c}\text { Five Phase } \\
\text { inverter Drive } \\
\text { with filter (\%) }\end{array}$ \\
\hline 1 & 100 & 100 \\
\hline 2 & 3.28 & 0 \\
\hline 3 & 32.94 & 20.82 \\
\hline 4 & 2.56 & 0 \\
\hline 5 & 2.53 & 0 \\
\hline 6 & 2.48 & 0 \\
\hline
\end{tabular}

\begin{tabular}{|c|c|c|}
\hline 7 & 14.87 & 6.51 \\
\hline 8 & 1.85 & 0 \\
\hline 9 & 9.77 & 4.83 \\
\hline 10 & 1.03 & 0 \\
\hline 11 & 9.64 & 3.85 \\
\hline 12 & 0.46 & 0 \\
\hline 13 & 8.89 & 3.12 \\
\hline 14 & 0.79 & 0 \\
\hline 15 & 0.77 & 0 \\
\hline 16 & 0.75 & 0 \\
\hline
\end{tabular}

\section{CONCLUSION}

The Five phase PWM drive is constructed using Simulink $\backslash$ MATLAB. The single tuned filter is designed and connected at the output of the inverter to study the harmonics and Total Harmonic Distortion of Five phase Inverter drive. The results have been compared with five phase inverter drive without filter and with tuned filter, from the results it found that the harmonic reduction and THD is found to be less with tuned filter five phase inverter drive.

This simulation work is implemented practically to study the temperature of the five phase induction motor for future work.

\section{REFERENCES}

[1] E. Levi, R. Bojoi, F. Profumo, H. A. Toliyat, and S. Williamson, "Multiphase induction motor drives-A technology status review", IET Elect. Power Appl., vol. 1, no. 4, pp. 489-516, Jul. 2007.

[2] Sk. Moin Ahmed, Member IEEE, Haitham Abu-Rub, Senior Member IEEE, AtifIqbal,Senior Member IEEE, M. Rizwan Khan and SaifullahPayami, "A Three-to-Five-Phase Matrix Converter Based Five-Phase Induction Motor Drive System", International Journal on Recent Trends in Engineering and Technology, Vol. 8, No. 2, Jan 2013

[3] Namhun Kim and Minhuei Kim, "Modified Direct Torque Control System of Five Phase Induction Motor", Journal of Electrical Engineering \& Technology Vol. 4, No. 2, pp. 266-271, 2009

[4] E. Levi, M. Jones, S. N. Vukosavic, H. A. Toliyat, "A Five-Phase Two-Machine Vector Controlled Induction Motor Drive Supplied from a Single Inverter", EPE Journal · Vol. 14 - no 3 - August 2004

[5] M. Jones and E. Levi, "A literature survey of state-of-the-art in multiphase ac drives", in Proc. 37th Int. UPEC, Stafford, U.K., 2002, pp. 505-510.

[6] E. Levi, "Multi-phase machines for variable speed applications,", EEE Trans. Ind. Electron., vol. 55, no. 5, pp.1893-1909, May 2008.

[7] K. P. Prasad Rao, B. Krishna Veni, D. Ravithej, "FIVE-LEG INVERTER for FIVE-PHASE SUPPLY", International Journal of Engineering Trends and Technology- Volume3Issue2- 2012

[8] S. K. Purushothaman, A Quantitative Approach to Minimize Harmonics Elimination Using Filter Design, International Journal of Advanced Research in Computer Science and Software Engineering, Volume 3, Issue 12, December 2013

[9] Dr Manjesh and Ananda A S, "Analysis and Study of Total Harmonic Distortion in Five Phase PWM Inverter using LC filter with neutral point DC link capacitor voltage balancing scheme", IEEE International Conference on Magentics, Machines and Drives- 2014.

[10] Devendra Mittal, Om Prakash Mahela, Rohit Jain, Electrical Power Quality Improvement In Faulty Conditions Using Three-Phase Double Tuned Harmonic Filter, INTERNATIONAL JOURNAL OF 
INNOVATIVE RESEARCH \& DEVELOPMENT, June, 2013 Vol 2 Issue 6

[11] Omar Turath Tawfeeq, THD Reduction of A Current Source Rectifier-DC Motor Drive Using Single Tuned Filters, International Journal of Inventive Engineering and Sciences (IJIES) ISSN: 23199598, Volume-1, Issue-12, November 2013

[12] Ananda A S and Dr. Manjesh, "Analysis of Harmonics in a Five phase PWM Inverter with LR load and mitigation of harmonics by $\pi$ filter", IEEE 2016 Biennial International Conference on Power and Energy Systems: Towards Sustainable Energy (PESTSE).

[13] ZUBAIR AHMED MEMON, MOHAMMAD ASLAM UQUAILI, AND MUKHTIAR ALI UNAR, Harmonics Mitigation of Industrial Power System Using Passive Filters, Mehran University Research Journal of Engineering \& Technology, Volume 31, No. 2, April, 2012

[14] Sumit Kanwar, Om Prakash Mahela, Devendra Mittal, Power Quality Improvement in Faulty Conditions using Tuned Harmonic Filters, IOSR Journal of Electrical and Electronics Engineering (IOSR-JEEE) e-ISSN: 2278-1676,p-ISSN: 2320-3331, Volume 6, Issue 5 (Jul. Aug. 2013)

[15] Ananda A S, Dr. Manjesh, Analysis of Harmonics in Five Phase Inverter Drive with Double tuned Filter using Simulink/MATLAB, International Journal of Advance Electrical and Electronics Engineering (IJAEEE) ISSN (Print): 2278-8948, Volume-4 Issue-2, Pg 1-4, 2015 